\title{
Solar Industrial Process Heating Systems in Operation -Current SHIP Plants and Future Prospects in Australia
}

\author{
Shahjadi Hisan Farjana ${ }^{a}$, Nazmul Huda ${ }^{a, n}$, M. A. Parvez Mahmud ${ }^{a}$, R. Saidur ${ }^{\text {b,c }}$ \\ ${ }^{a}$ School of Engineering, Macquarie University, Sydney, NSW-2109, Australia \\ ${ }^{b}$ Research Centre for Nano-Materials and Energy Technology (RCNMET), School of Science and Technology, Sunway University, No. 5, Jalan \\ Universiti, Bandar Sunway, Petaling Jaya, 47500 Selangor Darul Ehsan, Malaysia \\ ${ }^{c}$ Department of Engineering, Lancaster University, LA1 4YW,UK
}

\begin{abstract}
:
Solar thermal technology to supply process heat in different industrial sectors has become very promising in recent years. Industries can reduce their consumption of fossil fuels by replacing them with solar process heat with non-conventional system integration and using clean energy. In this paper, a systematic review of 10 countries is presented which demonstrated extensive use of solar industrial process heating systems in their manufacturing sectors. This country-wise analysis is then used to compare with current Australian scenario and identify future prospects of integrating solar process heating in Australian industrial sectors. The choice of countries is based on a database where promising industrial sectors and solar process heating applications are currently using incident solar energy. These are analyzed for their potential of integration to developing solar heat in industrial processes (SHIP) and a number of potential industrial sectors that have the highest potential like Motor vehicles, Textiles, Printing, Wood, Paper, Fabricated metal, Rubber and plastics, chemicals, Food, beverages, electrical equipment, machinery and equipment are being identified. An overview of available studies are discussed in this paper focused on specific countries and the industrial heat demand of existing operational plants. Future trends due to solar energy potential are also outlined.
\end{abstract}

Keywords: Solar industrial process heat, solar thermal energy, SHIP plants, Australia, Review.

\section{Introduction:}

From raw materials extraction to final production processing, process heat is a ubiquitous part of many industries. Over past decades, these have been much interest in buildings, residential areas, and industrial process heat applications. Fossil fuels and natural gas are used in manufacturing industries for process heat generation, which gives rise to greenhouse gas emissions, detrimental to a sustainable world.

Solar industrial process heating systems offer a solution for the sustainability problem through lower carbon emissions. These integrated systems are associated with the high capital cost of solar thermal collectors, which leads very few projects to come to fruition. Recently, solar thermal collectors have gone through significant improvements with the development of advanced modeling tools for solar collectors for solar process heat applications. As a result, the number of concentrating solar power (CSP) plants has increased dramatically, opening new research and development sectors for solar thermal developers using CSP collector technologies. The increase in the market size can help to decrease the cost of CSP collectors for IPH applications. The term "industrial process heat" will be referred to in this paper as solar IPH or "SHIP".

Solar thermal energy is converted heat from solar irradiation, in other words the eco-friendliest alternative to fossil fuel energy resources. Typically, thermal energy conversion systems use different combinations of solar collectors and solar concentrators powered by solar radiation for process heating in commercial or industrial plants. The major design specifications that should be considered include, collector type and position of installation, solar collector working fluid, system size, heat exchanger size and the load for specific applications.

The significant drawback of solar energy is unavailability for 24 hours. Supplementary process heating systems should be equipped to store the solar radiance. If the available solar radiation does not vary depending on season, a seasonal storage system is not needed. Seasonal variation is significant in regions with reduced radiation in winter. In areas where low range of solar radiation is available, like central Europe, to support competitive solar thermal technologies require substantial cost reductions.

Of the global final energy demand, electricity accounts for around $17 \%$ where low-temperature heat applications stand for $44 \%$ whereas high temperature industrial process heat occupies 10\%, and fuel used in transportation accounts for $29 \%$ (IPCC, 2007). Several potential studies have been conducted to identify suitable industrial processes, either globally or regionally where solar heat can be used, to demonstrate SHIP integration feasibility. Lauterbach et al. carried out a study to identify potential industrial processes and validated their feasibility based on TRANSYS simulation. Regional data, solar collector types, solar irradiance level data are processed through simulation [1]. Weiss et al. carried out an analysis to mark 10 suitable industries for solar heat integration and sought the solution for integration problems for those countries and institutes involved in the SolarPaces program [2].

Kalogirou et al. outlined a scientific way to choose the most appropriate and economical solar collector for a process heating system through a TRANSYS simulation based on location, on process temperature requirements [3]. Wohlgemuth et al. present an overview of solar energy and biofuel energy potential in industrial applications in developing countries [4]. Vajen et al. outlined the solar heat integration potential at supply level and process level in Europe, Germany and worldwide [5]. Michael 
et al. reviewed the research trend of solar thermal systems for industrial applications where there is a research gap in the low and medium temperature industrial heat processes [6]. Schmitt performed several comprehensive studies to show the utilized process installations in food and beverage industries. He also developed a classification mechanism for SHIP integration [7]. Sharma et al. reviewed solar industrial process heating systems in respect of utilization potential, present condition, solar collectors, solar industrial process heating systems integration potential, evaluation of system performance, economic assessment and barriers to large scale system integration. This paper also discussed about the current operating solar industrial process heating systems which are only written in existing literature works $[8,9]$.

There is no existing work which makes a global review of solar industrial process heating systems to determine dominating countries based on existing solar industrial process heating systems. Our country-wise analysis is further processed to clarify the immense potential of SHIP in the world's sunniest country- Australia to be utilized by the 5 largest industrial energy consumers. Section 2 describes the methodology followed to conduct this review analysis. Section 3 describes the solar thermal research initiatives taken in the 10 most advanced countries throughout the world. They are India, Austria, Germany, USA, Spain, China, South Africa, Mexico, France, and Greece. 10 countries are selected from the extensive survey conducted among the existing SHIP plants. Section 4 is used to find the potential of solar industrial process heating system in Australia through analyzing the solar energy potential followed by industrial energy consumption in Australia. Leading manufacturing sectors are also discussed here to identify the potential process stages where solar thermal energy could be in use. An extensive literature survey was done to investigate solar thermal research initiatives in Australia. Finally, the future potential of solar thermal in Australia is examined in comparison with countries that are playing a leading role in solar industrial process heating activities currently.

\section{Methodological Approach}

In this era of industrialization, nations and Governments are working on their own energy policy to make the world sustainable, which would need a drive towards zero carbon emission. The main goal of this review paper is to mark the solar thermal potential in the world's greatest sunny area, Australia. The potential is identified through detailed analysis and comparison among the advanced countries where the highest number of SHIP plants are on operation. At first, countries with largest number of solar industrial process heat plants are identified based on industrial sector, installed thermal capacity and installed collector area. Data are collected from SHIP plants database source and based on the highest number of SHIP plants in operation, potential countries are chosen. In the current scenario, potential countries are India, Austria, Germany, USA, Spain, China, South Africa, Mexico, France, and Greece. The leading industrial sectors of these potential countries are also discussed in this review paper. In the next stage, the SHIP plants operating in those countries are listed based on their key features like installed thermal capacity and industrial sector. Thus, a comprehensive literature review is conducted at this stage to categorize the country-wise case studies, for compilation of their results. In a later stage an extensive analysis is conducted comparing Australia, as the sunniest country in the continent and the identified countries based on their solar resources availability, manufacturing sector usability and renewable energy policy. After that, Australia is compared with the leading solar industrial process heating plant operating countries based on their key features, solar energy potential and industrial sector.

The methodology used in this paper is described as below. Steps 1 to 4 are described in section 3 while step 5 is illustrated in section 4 . The last step is analyzed in section 5 of this paper.

1. Solar industrial process heating plants throughout the world are sorted and categorized to identify the top ten potential countries with SHIP plants currently in operation.

2. The SHIP plants operated in the potential countries are analyzed to identify key industrial sectors within those countries.

3. SHIP plants within the identified industrial sectors are listed to identify highest capacity thermal plant in operation and their key features.

4. Extensive literature survey is conducted related to the potential countries and within their key industrial sectors to categorize their dominant features to flourish their solar industrial process heating potential.

5. Solar industrial process heating potential of Australia is analyzed based on solar energy potential, industrial energy consumption, key industrial sectors and solar thermal activities in Australia. Potential research works related to solar industrial process heating systems are also discussed here.

6. The key features of the 10 potential countries are compared with the Australian one to analyze the drawbacks and barriers towards solar industrial process heating systems to be used in Australia.

\section{Existing SHIP-country wise review}

Solar industrial process heat plants database information is used for identifying and categorizing countries that are already advanced with SHIP plant integration in their growing manufacturing industries. However, there would be some cases where solar energy for industrial process heat is not convenient due to difficulty in practical implementation. Even for industrial processes consume medium -temperature heat by using steam as a medium of working fluid, lower working temperatures would be sufficient for that purpose. First the accurate temperature required by the industrial process itself should be accessed to identify the feasibility of the integration, which should not be at the heat carrier temperature in use. This approach should be followed for lowering the process energy consumption. 
Table 1 is focused on a country based analysis of solar process heating systems based on the key industrial sectors- where solar heat is in use and where it is not. 10 countries are the focus of consideration, where current solar process heating systems are widely used in several industries. These countries already have SHIP plants in a wide range of manufacturing industries, where other industrial sectors still lack integration. Both are identified through this review work.

Table 1: Industrial Sectors and country-wise analysis.

\begin{tabular}{|c|c|c|}
\hline Country Name & Industrial Sectors using SHIP & $\begin{array}{l}\text { Industrial Sectors which are dominant but lack } \\
\text { renewable energy system integration }\end{array}$ \\
\hline India & $\begin{array}{l}\text { Agriculture, food, tobacco, textile, wearing apparel, leather, } \\
\text { paper, chemical, metals, electrical equipment, transport } \\
\text { equipment }\end{array}$ & pharmaceuticals, steel, mining \\
\hline Austria & Food, beverages, leather, chemicals, metals, furniture & $\begin{array}{l}\text { Electrics and Electronics industry and Wood, Pulp and Paper } \\
\text { industry }\end{array}$ \\
\hline Germany & $\begin{array}{l}\text { Agriculture, food, beverages, textiles, } \\
\text { chemicals, metals }\end{array}$ & automobiles, electrical equipment, \\
\hline USA & Agriculture, food, beverages, textiles, & $\begin{array}{l}\text { steel, motor vehicles, aerospace, chemicals, electronics, } \\
\text { mining }\end{array}$ \\
\hline Spain & Agriculture, food, textiles, wood, metals, motor vehicle & chemicals, pharmaceuticals, shipbuilding, automobiles, \\
\hline China & $\begin{array}{l}\text { Agriculture, food, beverages, textiles, } \\
\text { chemicals, leather }\end{array}$ & $\begin{array}{l}\text { mining and ore processing; iron and steel; aluminum; } \\
\text { coal; machinery; cement; automobiles, ships }\end{array}$ \\
\hline South Africa & Mining, food, beverages, machinery, motor vehicles & Automotive, electronics \\
\hline Mexico & Agriculture, food & $\begin{array}{l}\text { Aerospace, electronics, tobacco, chemicals, iron and steel, } \\
\text { mining, textiles, clothing, motor vehicles }\end{array}$ \\
\hline France & food and beverages, metals & $\begin{array}{l}\text { automobile manufacturing, aircraft production, chemicals, } \\
\text { electronics }\end{array}$ \\
\hline Greece & food, beverages, textiles, Pharmaceuticals, leather & Shipping, chemicals, metal products; mining \\
\hline
\end{tabular}

\subsection{India:}

India has a popular demand to use renewable energy sources. Indian industrial energy use reached 150 million tonnes of oil equivalent which accounts for $38 \%$ of the country's final energy used. The solar radiation over India has an average of 250-300 clear sunny days and 2300-3200 hours of sunshine per year. Indian industries are dominant in different sectors for using renewables to reduce greenhouse-gas emissions but still the pharmaceutical industries; mining and steel industries lack renewables which is crucial for their economy. However, in tobacco, paper, metals and wearing apparel sectors Indian industries are running with the highest capacity thermal power stations (Table 2). Though India has an immense potential in several industries; there is little existing literature works on SHIP in the food and paper industry in India.

Palaniappan described an interactive forum named the India Planters Energy Network - PEN, an NGO which has made a remarkable contribution to solar hot air technology for dehydration or drying things like tea leaves, spices, grains, salt, ceramic, fish, latex rubber, pulses and paddy etc. All these units are supplemented with conventional process heating units so that production in the factories is uninterrupted. PEN successfully demonstrated high-capacity hygienic processing of fish in India. PEN air heaters coupled with re-circulation driers could be used for drying organically grown fruits like mango, pineapple, and banana [10]. Sharma et al. conducted extensive studies to find the solar process heating potential in the paper industry and dairy industry in India by estimating the annual process heating requirement, specific thermal energy requirement, and from a survey of all Indian paper industries based on 8 locations and their requirements. Using the total process heating potential, the required solar collector area was also estimated [11, 12]. Uppal et al. reviewed Indian automobile industries, which consume large amounts of electricity or heat, followed by petroleum sources like natural gas as the second largest source. The total energy consumption in the automobile industry is mainly divided into three fields, Body shop, Paint shop and Assembly shop, where different production takes place in a well-defined sequence leading to a product consuming $73 \%$ of the total energy consumed in Paint shop, followed by $17 \%$ consumption in paint shop and $10 \%$ in the Assembly shop. Electricity consumed in Paint shop has a $45 \%$ share, leading to $35 \%$ share in the body shop and the rest $20 \%$ in the assembly shop. Natural gas is consumed in the Paint shop with a high share of $92 \%$, plus $4 \%$ in Body shop and $4 \%$ in the Assemble shop [13]. Suresh et al. developed a methodology to estimate the solar industrial process heating integration potential. They developed a methodology to integrate solar thermal collectors to meet process heating requirements. They also addressed the economic and developmental parameters set by solar energy council through key industries and sensitivity analysis [14].

Table 2: Solar Industrial Process Heat Plants Summary for India [15].

\begin{tabular}{|l|l|l|l|l|}
\hline $\begin{array}{l}\text { Industrial } \\
\text { Sector }\end{array}$ & $\begin{array}{l}\text { Number of } \\
\text { Industries }\end{array}$ & $\begin{array}{l}\text { Installed Thermal Power } \\
(\mathbf{k W t h}) \text { (maximum) }\end{array}$ & $\begin{array}{l}\text { Installed Collector } \\
\text { Area }\left(\mathbf{m}^{2}\right) \\
(\text { Maximum })\end{array}$ & Research Work and their key features \\
\hline
\end{tabular}




\begin{tabular}{|c|c|c|c|c|}
\hline Agriculture & 1 & 161 & 230 & $\begin{array}{l}\text { Palaniappan [10] - Developed solar hot air technology for drying } \\
\text { agricultural products. }\end{array}$ \\
\hline Food & 8 & 1008 & 1440 & $\begin{array}{l}\text { Sharma [12] - Survey of Indian dairy industries based on gross } \\
\text { energy requirements and annual process heating requirements. }\end{array}$ \\
\hline Tobacco & 1 & 220 & 900 & \\
\hline Textiles & 2 & 336 & 480 & \\
\hline Wearing apparel & 1 & 660.1 & 943 & \\
\hline Leather & 1 & 210 & 300 & \\
\hline Paper & 1 & 112 & 160 & $\begin{array}{l}\text { Sharma [11] - Survey of all Indian paper industries based on } \\
\text { their location and energy requirements. }\end{array}$ \\
\hline Chemicals & 1 & 448 & 640 & \\
\hline Basic metals & 1 & 354.2 & 506 & \\
\hline $\begin{array}{l}\text { Fabricated } \\
\text { metals }\end{array}$ & 1 & 72 & 400 & \\
\hline $\begin{array}{l}\text { Electrical } \\
\text { equipment }\end{array}$ & 2 & 224 & 320 & \\
\hline Machinery & 1 & 955.5 & 1365 & \\
\hline Motor vehicles & 1 & 125 & 180 & $\begin{array}{l}\text { Uppal [13] - Total electricity and heat requirements of the } \\
\text { automobile industries are analyzed based on their key industrial } \\
\text { sectors like body shop, assembly shop and paint shop. }\end{array}$ \\
\hline $\begin{array}{l}\text { Transport } \\
\text { equipment }\end{array}$ & 1 & 360 & 754.8 & \\
\hline General & & & & $\begin{array}{l}\text { Suresh [14] - Developed a methodology to integrate solar } \\
\text { thermal collectors meeting the process heating requirements and } \\
\text { validates through Indian industries like textile, dairy, leather and } \\
\text { automobile using economic and developmental parameters via } \\
\text { sensitivity analysis. }\end{array}$ \\
\hline
\end{tabular}

\subsection{Austria:}

In Austria, the upper region has more than 1 million square meter of solar collector installed. Solar market development is supported by a state energy strategy. The solar thermal collectors have been developed in Austria over the last two decades. Solar collector systems were installed in both existing buildings and principal heating system in new buildings. Austria is dominant in several industrial sectors for using solar process heating systems, like food and beverages, leather, chemicals and metals industries. In non-metallic metal industries, fabricated metal industries and the furniture sector, Austrian industries are identified as the highest-capacity solar thermal power stations with large collector area. But wood and pulp, paper and the electronics industries contribute a lot to the Austrian economy; which still lacks a focus of attention on renewables (Table 3).

Kranzl et al. provided an overview of the status and prospects of renewable energy in the heat sector of Austria until 2030. Upper Austria implemented their target in the space heating and hot water sectors. This paper analyzes the policy development of the Government for renewable energy in the heat sector (RES-H) [16]. Schnitzer et al. applied a newly developed investigation tool to investigate industrial energy systems and heat integration feasibilities through an Austrian dairy industry case study [17].

Table 3: Solar Industrial Process Heat Plants Summary for Austria [15].

\begin{tabular}{|l|l|l|l|l|}
\hline Industrial Sector & $\begin{array}{l}\text { Number of } \\
\text { Industries }\end{array}$ & $\begin{array}{l}\text { Installed Thermal Power } \\
(\mathbf{k W t h} \text { (maximum) }\end{array}$ & $\begin{array}{l}\text { Installed Collector Area } \\
\left(\mathbf{m}^{2}\right) \text { (Maximum) }\end{array}$ & Research Work and their key features \\
\hline Food products & 5 & 746.9 & 1067 & $\begin{array}{l}\text { Schnitzer [17] developed an } \\
\text { investigation tool to justify industrial } \\
\text { energy systems and heat integration } \\
\text { feasibilities through energy balance, } \\
\text { Sankey diagram, pinch analysis and cost } \\
\text { calculation. }\end{array}$ \\
\hline Beverages & & & 1520 & \\
\hline
\end{tabular}




\begin{tabular}{|l|l|l|l|l|}
\hline Leather & 1 & 53.9 & 77 & \\
\hline Chemicals & 1 & 29.4 & 42 & 1500 \\
\hline Non-metallic minerals & 2 & 1050 & 86 & \\
\hline Basic metals & 3 & 60.2 & 460 & \\
\hline Fabricated metals & 1 & 322 & 550 & \\
\hline Machinery & 2 & 61.6 & 88 & $\begin{array}{l}\text { Kranzl [16] reviewed the prospects of } \\
\text { heat energy in the Austrian industrial } \\
\text { sector, specifically the solar water } \\
\text { heating systems in use. }\end{array}$ \\
\hline Furniture & 1 & & & \\
\hline General & & & & \\
\hline
\end{tabular}

\subsection{Germany:}

Germany is successfully operating solar process heating systems in agriculture, beverages, basic metals and some other industries. Chemicals and chemical-product industries, food and beverages have a low-temperature heat demand. Hightemperature processes are mainly found in the heavy metal and non-metallic products heavy industries. Automobiles and electrical industries can also contribute in a meaningful way to reduce carbon dioxide emissions using renewables because of their dominance in the German industrial economy (Table 4).

Lauterbach et al. reviewed existing potential studies in the field of solar process heat where attention is given in industrial sectors in Germany. They identified and discussed 11 potential industrial sectors in Germany for integration of solar thermal energy. They also showed that the most important temperature range for SHIP integration in 100 to 200 degrees Celsius. They have also calculated and compared theoretical and technical solar energy potential in Germany [18, 19]. Frey et al. monitored a solar process heating system installed in a textile industry in Germany using a comprehensive monitoring system. They gave a general overview of the system and the monitoring results [20].

Table 4: Solar Industrial Process Heat Plants Summary for Germany [15].

\begin{tabular}{|c|c|c|c|c|}
\hline Industrial Sector & $\begin{array}{l}\text { Number of } \\
\text { Industries }\end{array}$ & $\begin{array}{l}\text { Installed Thermal } \\
\text { Power(kWth)(maximum) }\end{array}$ & $\begin{array}{l}\text { Installed Collector } \\
\text { Area }\left(m^{2}\right) \text { (Maximum) }\end{array}$ & $\begin{array}{l}\text { Research Work and their key } \\
\text { features }\end{array}$ \\
\hline Agriculture & 2 & 220 & 440 & \\
\hline Food & 1 & 397.6 & 568 & \\
\hline Beverages & 4 & 514.5 & 714 & \\
\hline Textiles & 1 & 50 & 100 & $\begin{array}{l}\text { Frey [20] investigated and identified } \\
\text { an installed solar industrial process } \\
\text { heating system consisting of } \\
\text { parabolic trough solar collector and } \\
\text { monitored for } 1 \text { year. The result } \\
\text { identified the solar potential } 21.8 \\
\text { MWh. }\end{array}$ \\
\hline Chemicals & 1 & 14.07 & 20.1 & \\
\hline Basic metals & 3 & 280 & 400 & \\
\hline Fabricated metals & 2 & 95.9 & 137 & \\
\hline Repairing \& installation & 1 & 30.1 & 43 & \\
\hline General & & & & $\begin{array}{l}\text { Lauterbach }[18,19] \text { reviewed } 11 \\
\text { industrial sectors for solar industrial } \\
\text { process heating system integration. } \\
\text { These sectors are Chemicals, Food } \\
\text { and beverages, Motor vehicles, } \\
\text { Paper, Fabricated metal, Machinery } \\
\text { and equipment, Rubber and plastic, } \\
\text { Electrical equipment, Textiles, } \\
\text { Printing and Wood. They identified }\end{array}$ \\
\hline
\end{tabular}




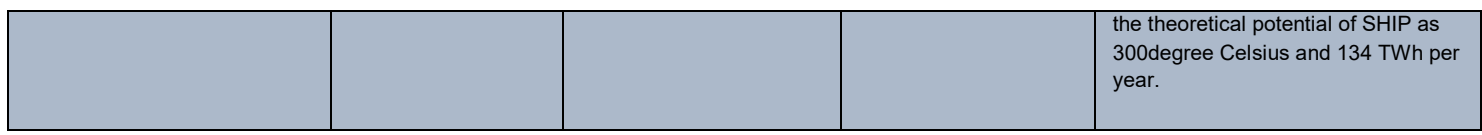

3.4. USA:

In the USA, manufacturing sectors like chemicals, food, paper, petroleum and primary metals have the greatest usage of natural gas. The U.S. food industry presents a particularly appealing target for many international SHIP plants. The food and beverages industries in the USA are already equipped with large-scale solar process heating systems. But chemicals, mining, metal and the electrical sectors should also be equipped with process system integration as major industrial sectors in the USA (Table 5).

Kurup et al. discussed the solar process heat potential in USA with special attention to California. They highlighted the top five users of industrial steam. Focusing on the food sector, they examined the solar resource potential and heat energy requirements of industrial consumers. They also focused on specific industries with the largest thermal energy requirements based on the temperature range of solar collectors [21].

Table 5: Solar Industrial Process Heat Plants Summary for USA [15]

\begin{tabular}{|l|l|l|l|l|}
\hline Industrial Sector & $\begin{array}{l}\text { Number of } \\
\text { Industries }\end{array}$ & $\begin{array}{l}\text { Installed Thermal } \\
\text { Power } \\
(\mathrm{kWth})(\text { maximum) }\end{array}$ & $\begin{array}{l}\text { Installed Collector } \\
\text { Area }\left(\mathrm{m}^{2}\right) \\
(\text { Maximum) }\end{array}$ & Research Work and their key features \\
\hline Agriculture & 1 & 7 & 10 & 7804 \\
\hline Food products & 9 & 5462.8 & $\begin{array}{l}\text { Kurup highlighted 5 industries in USA where the focus } \\
\text { is in California to identify the solar resource potential } \\
\text { and heat energy requirements. The potential analysis } \\
\text { identified 48 TWhth/year process heat demand in } \\
\text { different industries in California. }\end{array}$ \\
\hline Beverages & 4 & 2954.7 & 4221 & \\
\hline Textiles & 1 & 520.1 & 743 & \\
\hline
\end{tabular}

\subsection{Spain}

In Spain, the major process heat requirements in industrial sectors are shared by chemicals, food, beverages and tobacco, and paper industries. Other less energy-intensive industries are identified as textiles, wood, agriculture, fabricated metals and automobile industries. Among different solar process heating industries, agriculture has the most potential and operates with the world's largest capacity solar thermal power station in this sector. However, Spain has a great potential for solar process heating systems in automobiles, chemicals and the pharmaceuticals sector. Table 6 describes existing literature on SHIP in Spain.

Schweiger et al. reviewed the potential of solar industrial process heat from existing pilot plants in Spain and Portugal. They summarized recent developments in medium and high-temperature solar collectors and outlined future trends. They analyzed solar process heating system integration potential in 5 different locations based on a TRANSYS simulation (depending on solar collector technologies) [22]. Silva et al. studied possibility of a parabolic trough solar-collector based process heat steam generation system for the food processing industries [23].

Table 6: Solar Industrial Process Heat Plants Summary for Spain [15].

\begin{tabular}{|c|c|c|c|c|}
\hline Industrial Sector & $\begin{array}{l}\text { Number of } \\
\text { Industries }\end{array}$ & $\begin{array}{l}\text { Installed Thermal } \\
\text { Power(kWth)(maximum) }\end{array}$ & $\begin{array}{l}\text { Installed Collector Area } \\
\left(m^{2}\right)(\text { Maximum })\end{array}$ & Research Work and their key features \\
\hline Agriculture & 1 & 921.2 & 1316 & $\begin{array}{l}\text { Schweiger [22] analyzed the solar industrial } \\
\text { process heating systems of various industrial } \\
\text { sectors within Europe, like food, textile, wood, } \\
\text { paper, chemical and timber. They analyzed the } \\
\text { potential and requirements of solar industrial } \\
\text { process heating systems within five different } \\
\text { cities of Spain and Portugal based on } \\
\text { TRANSYs simulation. The results showed } \\
\text { annual energy gain of } 400 \text { to } 1000 \mathrm{kWh} / \mathrm{m} 2 \\
\text { which are obtained for } 100 \text {-degree Celsius }\end{array}$ \\
\hline
\end{tabular}




\begin{tabular}{|l|l|l|l|l|}
\hline & & & & solar heat. \\
\hline Food products & 5 & 203 & 290 & $\begin{array}{l}\text { Silva [23] analyzed the potential of using } \\
\text { parabolic trough solar collector based solar } \\
\text { industrial process heating systems in the food } \\
\text { industries. }\end{array}$ \\
\hline Textiles & 1 & 33 & 47.15 & \\
\hline Wood & 1 & 30.8 & 44 & \\
\hline Fabricated metals & 1 & 26 & 180 & \\
\hline Motor vehicles & 2 & 370 & 530 & \\
\hline
\end{tabular}

3.6. China

The most prosperous industrial sectors in China are mining and ore processing like iron, steel, aluminum, coal, cement and automobiles, which can contribute in a meaningful way for building a sustainable environment by adopting solar process heating systems. Currently only a few industries are operating with renewable process heating systems, like agriculture, food and beverages, textiles, leather and chemicals (Table 7).

Sturm et al. analyzed three different steam-generation systems for supplementary steams to reduce the thermal energy demand. They tried to integrate renewable energy thus intensification of heating process [24]. Liu et al. studied the industrial energy use in China's economy in 2007 by conducting an input-output analysis. They compared the actual energy consumption with the energy demand in 29 industrial sectors for their production processes [25].

Table 7: Solar Industrial Process Heat Plants Summary for China [14].

\begin{tabular}{|l|l|l|l|l|}
\hline Industrial Sector & $\begin{array}{l}\text { Number of } \\
\text { Industries }\end{array}$ & $\begin{array}{l}\text { Installed Thermal Power } \\
(\mathrm{kWth})(\text { maximum) }\end{array}$ & $\begin{array}{l}\text { Installed Collector Area } \\
\left(\mathrm{m}^{2}\right) \text { (Maximum) }\end{array}$ & Research Work and their key features \\
\hline Agriculture & 1 & 252 & 360 & $\begin{array}{l}\text { Sturm [24] analyzed three different steam } \\
\text { generation system of Chinese condiment sector to } \\
\text { intensify process heat generation system. }\end{array}$ \\
\hline Food products & 2 & 276.5 & 395 & \\
\hline Beverages & 2 & 696.5 & 995 & \\
\hline Textiles & 2 & 9000 & 13000 & $\begin{array}{l}\text { Liu [25] analyzed 40 different industrial sectors } \\
\text { and studied the industrial energy demand and } \\
\text { economy in China focusing towards 2007 based } \\
\text { on input-output analysis. }\end{array}$ \\
\hline Leather & 1 & 441 & 630 & \\
\hline General & & & & \\
\hline
\end{tabular}

\subsection{South Africa:}

The most promising energy-consuming sectors identified are metal and plastic treatment and chemicals, food (including wine and beverage), textiles. The available high-capacity solar radiation provides significant scope for solar industrial process heat applications. Automotive and electronics industries still the focus of attention to use renewables for process heating applications. Table 8 describes existing literature on SHIP in South Africa.

Brent et al. studied international trends and drivers for concentrating solar thermal systems to examine the specific potential of South Africa [26]. Uhlig et al. identified available technologies to show the potential of concentrating solar thermal technology for using high-temperature process heat [27]. Joubert et al. researched large-scale solar thermal systems in South Africa, where 89 systems are analyzed based on cost, applications and industries [28].

Table 8: Solar Industrial Process Heat Plants Summary for South Africa [15].

\begin{tabular}{|l|l|l|l|l|}
\hline Industrial Sector & Number of & Installed Thermal Power & $\begin{array}{l}\text { Installed Collector } \\
\text { Area }\left(\mathrm{m}^{2}\right)\end{array}$ & Research Work and their key features \\
\hline
\end{tabular}




\begin{tabular}{|c|c|c|c|c|}
\hline & Industries & (kWth)(maximum) & (Maximum) & \\
\hline Mining and quarrying & 5 & 378 & 540 & \\
\hline Beverages & 1 & 84 & 120 & \\
\hline Motor vehicles & 1 & 140 & 200 & \\
\hline General & & & & $\begin{array}{l}\text { Brent [26], Uhlig [27] and Joubert [28] all } \\
\text { researchers analyzed and the international trends } \\
\text { in the respect of solar thermal energy generation } \\
\text { system in South Africa and potential to employ } \\
\text { high temperature process heating technologies to } \\
\text { the industrial systems. }\end{array}$ \\
\hline
\end{tabular}

\subsection{Mexico}

The Mexican industrial sector consumes $28 \%$ of the total energy, including all the production processes. Fuel is an important factor for process heat generation and is a determinant for the industrial economy. Mexican solar energy is an abundant resource. In future, Mexican industries which can adopt solar process heating systems include: agriculture, tobacco, chemical and mining industries. Table 9 describes existing SHIP plants in Mexico.

Ramos et al. studied small and the micro-sized textile and food industries in Mexico based on statistical information to investigate any parabolic-trough technology applied in those industries [29].

Table 9: Solar Industrial Process Heat Plants Summary for Mexico [15].

\begin{tabular}{|l|l|l|l|l|}
\hline Industrial Sector & $\begin{array}{l}\text { Number of } \\
\text { Industries }\end{array}$ & $\begin{array}{l}\text { Installed Thermal } \\
\text { Power } \\
(\mathrm{kWth}) \text { (maximum) }\end{array}$ & $\begin{array}{l}\text { Installed Collector } \\
\text { Area }\left(\mathrm{m}^{2}\right) \text { (Maximum) }\end{array}$ & Research Work and their key features \\
\hline Agriculture & 1 & 36 & 66 & $\begin{array}{l}\text { Ramos [29] tried to integrate parabolic trough solar } \\
\text { collector based SHIP systems to the Mexican food and } \\
\text { textile industries. They have shown that these } \\
\text { industries are responsible for total } 68 \% \text { thermal energy } \\
\text { consumption which is driven by natural gas and diesel } \\
\text { which could easily be replaced by parabolic trough } \\
\text { solar collector systems in terms of their capacity. }\end{array}$ \\
\hline Food & 9 & 240 & 430 & \\
\hline
\end{tabular}

\subsection{France:}

In France, solar process heat is being utilized in 4 different industries in food, beverage and fabricated metal industries with flatplate collector and evacuated-tube collector technologies. The industrial process operations may be the bottle cleaning process, cooling of wine cellar (absorption chiller $52 \mathrm{~kW}$ capacity) and for heating up an alkaline cleaning bath. Food and beverage fabricated metal industries are operating with solar process heating systems; however automobile and chemical manufacturers can also consider solar process heating system integration. Table 10 describes existing SHIP plants in France.

Table 10: Solar Industrial Process Heat Plants Summary for France [15].

\begin{tabular}{|l|l|l|l|}
\hline Industrial Sector & $\begin{array}{l}\text { Number of } \\
\text { Industries }\end{array}$ & $\begin{array}{l}\text { Installed Thermal } \\
\text { Power } \\
(\mathrm{kWth})(\text { maximum) }\end{array}$ & $\begin{array}{l}\text { Installed Collector Area } \\
\left(\mathrm{m}^{2}\right) \text { (Maximum) }\end{array}$ \\
\hline Food & 1 & 1050 & 1500 \\
\hline Beverages & 2 & 151.2 & 216 \\
\hline Fabricated Metals & 1 & 126 & 180 \\
\hline
\end{tabular}


3.10.Greece:

1

Greece operates many solar industrial process heat plants in the food, beverages, textiles, pharmaceuticals or leather products industries, where the dominating sector is the food industry. In Greece, chemical and mining industries are operating and contributing significantly to their economy, however with non-renewable process heating systems which have great potential to shift towards renewables. Table 11 describes existing SHIP plants in Greece.

Karagiorgas et al. evaluated industrial solar thermal systems and compared with fossil-fuel powered energy equivalent systems through the presentation of 8 successful applications of solar thermal systems [30].

Table 11: Solar Industrial Process Heat Plants Summary for Greece [14].

\begin{tabular}{|l|l|l|l|l|}
\hline Industrial Sector & Number of Industries & $\begin{array}{l}\text { Installed Thermal Power } \\
(\mathrm{kWth})(\text { maximum) }\end{array}$ & $\begin{array}{l}\text { Installed Collector Area } \\
\left(\mathrm{m}^{2}\right)(\text { Maximum) }\end{array}$ & Research Work and their key features \\
\hline Food & 5 & 728 & 1040 & $\begin{array}{l}\text { Karagiorgas [30] evaluated and compared } \\
\text { solar thermal systems with fossil fuel } \\
\text { powered energy equivalent systems. }\end{array}$ \\
\hline Beverages & 1 & 215.6 & 308 & \\
\hline Textiles & 2 & 121.8 & 174 & \\
\hline Pharmaceuticals & 1 & 1890 & 2700 & \\
\hline Leather Products & 1 & 210 & 300 & \\
\hline
\end{tabular}

\subsection{Other Countries}

Other countries, based on their current focus on utilizing solar process heat in industrial systems on very small scales are analyzed separately based on their current use and future potential of integrating process heating systems through renewables by categorizing the key industrial sectors which are dominant in their economy. Table 12 describes existing literature on SHIP in different countries.

Table 12: Solar Industrial Process Heat Plants Summary for other countries [14]

\begin{tabular}{|c|c|c|c|c|}
\hline Country & Industrial Sector & $\begin{array}{l}\text { Number of } \\
\text { Industries }\end{array}$ & $\begin{array}{l}\text { Installed Thermal Power (kWth) } \\
\text { (maximum) }\end{array}$ & $\begin{array}{l}\text { Installed Collector Area }\left(\mathrm{m}^{2}\right) \\
\text { (Maximum) }\end{array}$ \\
\hline \multirow[t]{2}{*}{ Egypt } & Pharmaceutical Products & 1 & 1330 & 1900 \\
\hline & Chemical Products & 1 & 26.88 & 38.4 \\
\hline \multirow{2}{*}{$\begin{array}{l}\text { Czech } \\
\text { Republic }\end{array}$} & Food & 1 & 14 & 20 \\
\hline & Beverages & 1 & 25.2 & 36 \\
\hline \multirow[t]{2}{*}{ Thailand } & Leather & 2 & 1323 & 1890 \\
\hline & Rubber & 1 & 56 & 80 \\
\hline \multirow[t]{3}{*}{ Vietnam } & Leather & 1 & 700 & 1000 \\
\hline & Textile & 1 & 336 & 480 \\
\hline & Wearing Apparel & 1 & 493.5 & 705 \\
\hline Argentina & Tobacco & 1 & 515.9 & 737 \\
\hline Chile & Mining and quarrying & 2 & 27510 & 39300 \\
\hline Costa Rica & Food & 1 & 602 & 860 \\
\hline Cyprus & Mining and quarrying & 1 & 532 & 760 \\
\hline
\end{tabular}




\begin{tabular}{|l|l|l|l|l|}
\hline Indonesia & Food & 1 & 420 & 600 \\
\hline Israel & Food & 1 & 246 & 244 \\
\hline Italy & Food & 1 & 470 & 995 \\
\hline Jordan & Food & 1 & 84 & 120 \\
\hline Kenya & Leather & 1 & 406 & 580 \\
\hline $\begin{array}{l}\text { Netherland } \\
\text { s }\end{array}$ & Food & 1 & 1680 & 2400 \\
\hline Panama & Food & 1 & 630 & 900 \\
\hline Romania & Agriculture & 2 & 56 & 80 \\
\hline $\begin{array}{l}\text { Saudi } \\
\text { Arabia }\end{array}$ & Beverages & 1 & 360.5 & 515 \\
\hline Sweden & Computer Products & 1 & 84 & 100 \\
\hline Tunisia & Beverages & 1 & 40 & 120 \\
\hline
\end{tabular}

4. SHIP in Australia

Australia has immense potential for solar industrial process heating systems, being the sunniest country in the world. This section thus describes solar energy potential in Australia and the energy consumption in industrial sectors, thus discusses the key industrial sectors and solar thermal activities in Australia.

\subsection{Solar Energy Potential}

As the sunniest country in the world, the incident solar radiation in Australia has the highest average of the whole world. The annual solar radiation falling in Australia is about 10000 times its annual energy consumption, which is 58 million peta joules. Of the Australian states, Western Australia is the largest consumer of solar thermal energy followed by New South Wales and Queensland. After setting a wide range of Government or state Government policies, the use of solar water heating systems in residential and building sectors has dramatically improved over the decades. $830 \mathrm{GWh}$ of solar energy was used in Australia in 2002, where domestic water heating contributes $61 \%$. Australia's solar energy activities are confined to domestic hot water heating and off-grid installations only, currently which have an immense potential to be applied in low-temperature industrial process heating systems [31, 32].

\subsection{Industrial Energy Consumption}

In 2013-2014, the manufacturing sector accounted for $20 \%$ of the total net energy consumption, down from $22 \%$ in the previous year. In contrast to growth in 2012-13, energy consumption in the manufacturing sector fell by $7 \%$ in $2013-14$, underpinned by a fall in energy use in the petroleum refining, non-ferrous metals, and food, beverage and tobacco sectors. Energy consumption in the mining sector continued to grow strongly in $2013-14$, by nearly $7 \%$, supported by significant increases in production across a range of resources and energy commodities. Energy use in oil and gas extraction increased by nearly $11 \%$, underpinned by growth in gas production for domestic use in Queensland and Western Australia. Expansion of iron ore production in Western Australia supported growth in energy use in other mining as well [4, 31-35].

Table 13 illustrates the energy consumption in Australian industries by sector. The data shown here is collected from the Department of Industry and Science (2015) Australian Energy Statistics. Energy consumption by ferrous metals is 496.4 peta Joules (PJ) in 2013-14. Non-ferrous metal industries stand for 402.7 peta Joules. Ferrous metal industries are the highest one sharing $41.9 \%$ of the whole energy usage by industries. The total energy consumption in 2013-14 was 1186.2 peta Joules. So, in summary metal and mining industries accounts for $75.8 \%$ whole industrial energy consumption in Australia [4, 31-35].

Table 13 Australian manufacturing energy consumption, by subsector [33]

\begin{tabular}{|l|l|}
\hline Industrial Sector & $\begin{array}{l}\text { Energy Consumption in 2013-2014 in } \\
\text { PJ }\end{array}$ \\
\hline Ferrous metals & 496.4 \\
\hline
\end{tabular}




\begin{tabular}{|l|l|}
\hline Non-ferrous metals & 402.7 \\
\hline Chemicals & 232.4 \\
\hline Food, beverages and tobacco & 153.4 \\
\hline Agriculture & 99.7 \\
\hline Wood, paper & 70.4 \\
\hline
\end{tabular}

\subsection{Key Industrial Sectors}

The whole industrial sector in Australia could be subdivided into mining industry, manufacturing industry and agricultural industry.

Mining industry is the primary contributor to the Australian economy. The mining industry brings 138 billion AUD per annum which constitutes $54 \%$ of total. Mining is responsible for about $7 \%$ of Australian GDP. As one of the largest producers of mineral commodities including aluminum, copper, gold, iron, mineral sands, zinc and coal. Australia is the world's largest producer of bauxite and opal and the largest exporter of coal. At the same time, it holds the position of the world's second largest producer of iron ore, gold, zinc production. The mining industries are scattered throughout Australia.

Agricultural industry is responsible for $3 \%$ of Australia's GDP. More than 300,000 people are employed in the agricultural sector, where the annual turnover is 155 billion AUD per year. The major products are cattle, wheat, milk, fruits and nuts, vegetables, wool, barley, poultry, lambs and sugar cane.

Australian manufacturing industry is responsible for around $12 \%$ of its GDP. The manufacturing industry has several sectors like food and beverages, textile, wood and paper, chemicals, machinery, motor vehicles etc. Most of the manufacturing industries are situated in New South Wales followed by Victoria [4, 31-35].

\subsection{Solar Thermal Activities in Australia}

There are several research initiatives to investigate the potential of solar energy utilization in Australia. Bahadori et al. conducted a study focused on the necessity to improve the solar energy utilization in Australia, including the current scenario and future potential. This paper analyzes both solar PV and solar thermal systems. They showed that solar energy can significantly contribute in future to Australia's electricity supply grid [37]. Eglinton et al. reviewed the potential of concentrating solar thermal technology while attention is for high temperature processes in the Australian mineral processing and metallurgical industry [38]. Baig et al. researched the feasibility of integrating concentrating solar power systems in Northern Territory mining industries. As the Northern Territory is the region with the highest solar radiation intensity, major concern is finding the design requirements and costs for future solar integrated zero-carbon emission mining industries [39]. Fuller reviewed solar drying technologies installed and operating in Australian agricultural industries since 1960.In another paper, Fuller also reviewed the past activity in SHIP in Australia and the lessons learned from it for future progress in SHIP [40, 41]. Beath reviewed the industrial energy usage for Australia from 2498 individual sites by their unique characteristics - location, industry type, energy use, characteristic process temperature [42].

Australia is the world's sunniest continent with enormous, but largely underutilized, potential for solar power generation. As the solar industry grows, it opens opportunities for small businesses, investment and jobs in solar installation and maintenance. China is the world solar investment leader, setting a one-year record in 2012 with US $\$ 31.2$ billion invested. Solar capacity doubled in 2012 and China intends to triple that capacity in another two years. Germany receives less sunlight than Victoria but has more installed capacity than any other country due to a significant program of policy support. Globally, the cost of producing solar panels fell 75\% between 2008 and 2011. Total global investment in solar energy grew to US $\$ 140$ billion in 2012. Total global installed solar PV capacity grew by $42 \%$ in 2012 , four times its level in 2009 . Solar will become a more and more important part of the Australian energy mix into the future $[4,31-35,43-50]$. 
5. Discussion:

Table 14: Comparison based on industrial sectors and their highest-capacity SHIP plant in operation.

\begin{tabular}{|c|c|c|c|c|c|}
\hline $\begin{array}{l}\text { Industrial } \\
\text { Sector }\end{array}$ & $\begin{array}{l}\text { Number of } \\
\text { Industries }\end{array}$ & $\begin{array}{l}\text { Highest Capacity Plant in } \\
\text { Operation }\end{array}$ & Process Operation & $\begin{array}{l}\text { Installed Thermal } \\
\text { Power (kWth) } \\
\text { (maximum) }\end{array}$ & $\begin{array}{l}\begin{array}{l}\text { Installed Collector Area } \\
\left(\mathrm{m}^{2}\right)\end{array} \\
\text { (Maximum) }\end{array}$ \\
\hline Food & 59 & USA -Prestage Food & Water heating & 5462.8 & 7804 \\
\hline Beverage & 21 & USA -Gatorade & Water preheating & 2954.7 & 4221 \\
\hline Textiles & 10 & China -Daly Textile & Water heating & 9000 & 13000 \\
\hline Agriculture & 9 & $\begin{array}{l}\text { Spain - Acuinova Andalucia } \\
\text { S.A. }\end{array}$ & Water heating & 921.2 & 1316 \\
\hline $\begin{array}{l}\text { Mining \& } \\
\text { Quarrying }\end{array}$ & 8 & $\begin{array}{l}\text { Chile -Codelco Gabriela } \\
\text { Mistral }\end{array}$ & Electro winning Process & 27510 & 39300 \\
\hline $\begin{array}{l}\text { Fabricated } \\
\text { metals }\end{array}$ & 7 & Austria - Julius Blum & $\begin{array}{l}\text { Heating of the pre-treatment } \\
\text { washbasins }\end{array}$ & 322 & 460 \\
\hline $\begin{array}{l}\text { Basic } \\
\text { metals }\end{array}$ & 6 & India -Kangaroo India Limited & Nickel bath & 354.2 & 506 \\
\hline Chemicals & 5 & $\begin{array}{l}\text { China -Solar Steam Boiler for } \\
\text { Product \& Gamble(Tianjin) }\end{array}$ & Steam generation & 1050 & 4600 \\
\hline Machinery & 5 & India - Wheels India & Water heating & 955.5 & 1365 \\
\hline $\begin{array}{l}\text { Motor } \\
\text { vehicles }\end{array}$ & 4 & Spain- Nissan Avila & Bodyworks pre-treatment line & 370 & 530 \\
\hline Paper & 1 & India- B.S. Paper Mill & Different process applications & 112 & 160 \\
\hline Wood & 1 & Spain- Instituto Del Corcho & Cork cooking & 30.8 & 44 \\
\hline
\end{tabular}

There were several research pathways for solar industrial process heating potential analysis. Identification of potential industrial processes, identification of efficient solar collector based on location, solar process heat integration mechanism, problem and solution. So far different methods have been reported, either by global or by regional analysis. This review only focuses on the research and review works, to identify solar industrial process heating potential. Lauterbach, Wohlgemuth, Kurup reviewed potential industrial sectors [1, 2, 4]. Weiss tries to point out the solar industrial process heating systems integration problems and tries to find their solution. Kalogirou suggested suitable solar collector types depending on weather data using a TRNSYS simulation [2]. Schmitt proposes a classification mechanism for SHIP [7]. Solar heat utilization in industrial production processes is analyzed and compared among 23 industrial sectors which constitute of 159 industries throughout the world. The 159 industries cover 30 countries like USA, China, India and several European countries. All those industries are compared based on their respective process operation, installed thermal power $(\mathrm{kWth})$ and installed collector area $\left(\mathrm{m}^{2}\right)$. The Table 15 showed that in Chile Codelco Gabriela Mistral is the highest capacity thermal power (27510kWth) unit, operating with the largest solar collector area of all $\left(39300 \mathrm{~m}^{2}\right)$. India is operating a huge number of SHIP plants with the total highest capacity and collectors are constructed for basic metals, machinery, electrical equipment, tobacco, wearing apparel, paper and transport equipment sectors. Austria has the highest thermal powered and large collectors installed fabricated metal, non-metallic products and furniture industry. Then comes China and USA, where USA is presiding for major industrial sectors like food and beverage and China is working for textile and chemical industry. The process operations which are involved in these industries are - water heating, air drying, water preheating, steam generation, retanning and electro-winning process, etc. [51-58].

Table 15 discussed the share of global capacity of solar water heating collectors of the world, their key manufacturing sectors and major research aspects. Firstly, India stands for $1.2 \%$ of the total world's global capacity of solar water heating systems where food and agriculture are the leading industrial sector employing SHIP systems. India has extensive research focus on solar drying technique focused in agriculture and food sector. Then comes Austria which have capacity of $1 \%$ of global capacity of solar water heating based collector systems and SHIP systems are based on food industries as like in India. In Austria, industrial energy systems and heat based renewable energy systems integration feasibility of various manufacturing sectors. By successful integration of several energy techniques, renewable energy resources would be able to replace fossil fuel based thermal energy generation technologies. Next comes Germany where beverage industries are the key manufacturing sectors 
with 3.3\% potential of global solar thermal systems and key research focused on implementation and efficiency calculation of parabolic trough solar collector based SHIP systems. Then comes USA which has larger solar thermal collector capacity potential than India, China and Austria. Here, research focus is confined on California based solar resources potential based on gross energy requirements by industries located there. Next comes Spain which shows similar trend like USA. The next position goes for world's largest potential country for solar thermal capacity of collectors used in water heating, that is China. Chinese SHIP industries rely on food industry mostly where industrial energy consumption is analyzed in the respect of SHIP based on economic input-output analysis. Similar trend is noticed for South Africa, Mexico, Greece and France. While the question comes about Australia, the key industrial sectors are mining and agricultural industries. According to research challenges, Australia based researcher community is focused on potential of successful integration of solar industrial process heating technologies with conventional thermal energy generation sources in mining industries. The research work is also undertaken in solar drying technologies and for the identification of key industrial energy consumable sectors [59-68].

From critical analysis towards Australia versus SHIP countries, there could have some reasons behind lack of solar industrial process heating systems in Australia. At first, the key manufacturing sector in Australia is the ferro and no-ferro based mining industries. Mining industries generally require high temperature process heat to perform their operations which is still rare throughout the world. Based on the supply of solar process heat, SHIP plants integration with the focus on mining industries still lack attention. Secondly, as the minerals and mines are going deeper, the more energy intensive would the process become. Because it is hard to deliver high temperature solar process heating systems by him. So, by extensive use of non-renewable energy generation resources, emissions are rapidly increasing which might be possible to reduce using solar industrial process heating systems integration. Thirdly, coal fuel is very abundant and cheap in Australia which leads to lack of attention towards solar process heat integration. Fourthly, high capital costs associated with the new solar thermal collector installation is another main reason for less use of solar process heat. Finally, significant research work lacks focus of attention towards how to integrate solar industrial process heating systems, what to integrate. In short, for advancement of SHIP use in Australia, significant research work is necessary to reduce the high capital cost of installation and to achieve high temperature thermal energy from solar process heat [69-71].

Table 15 Comparison among the existing literature on SHIP.

\begin{tabular}{|c|c|c|c|}
\hline $\begin{array}{l}\text { Country } \\
\text { Name }\end{array}$ & $\begin{array}{l}\text { Share of the } \\
\text { global capacity } \\
\text { of solar water } \\
\text { heating } \\
\text { collectors }\end{array}$ & Industrial Sectors using SHIP & Major Research Aspects \\
\hline India & $1.2 \%$ & $\begin{array}{l}\text { Agriculture, food, tobacco, } \\
\text { textile, wearing apparel, leather, } \\
\text { paper, chemical, metals, } \\
\text { electrical equipment, transport } \\
\text { equipment }\end{array}$ & $\begin{array}{ll}\text { 1. } & \text { Solar hot air technology. } \\
\text { 2. Annual process heating requirement, specific thermal } \\
\text { energy requirement. }\end{array}$ \\
\hline Austria & $1 \%$ & $\begin{array}{l}\text { Food, beverages, leather, } \\
\text { chemicals, metals, furniture }\end{array}$ & $\begin{array}{l}\text { 1. Industrial energy systems and heat integration } \\
\text { feasibilities. } \\
\text { 2. Renewable energy in the heat sector until } 2030 .\end{array}$ \\
\hline Germany & $3.3 \%$ & $\begin{array}{l}\text { Agriculture, food, beverages, } \\
\text { textiles, } \\
\text { chemicals, metals }\end{array}$ & $\begin{array}{l}\text { 1. } 11 \text { potential industrial sectors. } \\
\text { 2. } \quad \text { Solar process heating systems. }\end{array}$ \\
\hline USA & $4.5 \%$ & $\begin{array}{l}\text { Agriculture, food, beverages, } \\
\text { textiles, }\end{array}$ & 1. Solar process heat potential in USA. \\
\hline Spain & & $\begin{array}{l}\text { Agriculture, food, textiles, wood, } \\
\text { metals, motor vehicle }\end{array}$ & $\begin{array}{l}\text { 1. Parabolic-trough solar-collector based process heat } \\
\text { steam generation system. }\end{array}$ \\
\hline China & $70 \%$ & $\begin{array}{l}\text { Agriculture, food, beverages, } \\
\text { textiles, } \\
\text { chemicals, leather }\end{array}$ & $\begin{array}{l}\text { 1. Industrial energy use by conducting an input-output } \\
\text { analysis throughout the industries. } \\
\text { 2. Three different steam generation system. }\end{array}$ \\
\hline $\begin{array}{l}\text { South } \\
\text { Africa }\end{array}$ & & $\begin{array}{l}\text { Mining, food, beverages, } \\
\text { machinery, motor vehicles }\end{array}$ & $\begin{array}{l}\text { 1. Concentrating solar thermal technology for high- } \\
\text { temperature process heat. } \\
\text { 2. Large-scale solar thermal systems worked as solar water } \\
\text { heating systems. }\end{array}$ \\
\hline Mexico & & Agriculture, food & $\begin{array}{l}\text { Small and micro-sized industry based parabolic trough } \\
\text { technology in food and textile industries. }\end{array}$ \\
\hline France & & food and beverages, metals & \\
\hline Greece & $0.8 \%$ & $\begin{array}{l}\text { food, beverages, textiles, } \\
\text { Pharmaceuticals, leather }\end{array}$ & $\begin{array}{l}\text { 1. Industrial solar thermal systems with fossil fuel } \\
\text { empowered energy equivalent systems. }\end{array}$ \\
\hline Australia & $1.5 \%$ & & $\begin{array}{l}\text { 1. The potential of concentrating solar thermal technology. } \\
\text { 2. Feasibility of integrating concentrating solar power } \\
\text { systems in Northern Territory mining industries. } \\
\text { 3. Solar drying technologies installed and operating in } \\
\text { Australian agricultural industries. } \\
\text { 4. Industrial energy usage for Australia. }\end{array}$ \\
\hline
\end{tabular}


In this review paper, overall 10 countries are analyzed for their current potential and prospects of solar process heating system integration in their major industries. Key industrial sectors where process heating systems can replace fossil fuels to reduce carbon-dioxide and greenhouse-gas-emissions are also identified based on their economy. Future research scope for integrating solar process heating systems in industries is also suggested. In summary, this paper aims to find out the worldwide potential of solar industrial process heating system and what is the reason behind less use of solar industrial process heating systems in Australia, which is responsible for vast effects of greenhouse gas emissions. This paper also tried to address the measures to be taken to reduce the environmental effects through successful integration of solar industrial process heating systems in Australian manufacturing sectors.

References:

[1] Lauterbach C, Rad SJ, Schmitt B, Vajen K. Feasibility assessment of solar process heat applications. 30th ISES Bienn Sol World Congr 2011, SWC 2011 2011;4:3361-70.

[2] Weiss W, Schweiger H, Battisti R. Market potential and system designs for industrial solar heat applications n.d.:2-7.

[3] Kalogirou S. the Potential of Solar Energy in Food-Industry Process Heat Applications. J Chem Inf Model 2013;53:1689-99. doi:10.1017/CBO9781107415324.004.

[4] Pro A, Chie M, Pro C, Ac TR, Millenniu N. Renewable Energy for Industrial Applications 2015.

[5] Vajen K. Solar heat for industrial processes-Potential, technologies and applications. Int ... 2012:22-3.

[6] Michael MB, Akinlabi ET, Jen T. A Review of Solar Thermal Systems Utilization for Industrial Process Heat Applications 2016;II:19-23.

[7] Schmitt B. Classification of Industrial Heat Consumers for Integration of Solar Heat. Energy Procedia 2016;91:65060. doi:http://dx.doi.org/10.1016/j.egypro.2016.06.225.

[8] Sharma AK, Sharma C, Mullick SC, Kandpal TC. Solar industrial process heating: A review. Renew Sustain Energy Rev 2017;78:124-37. doi:10.1016/j.rser.2017.04.079.

[9] Sharma A, Chen CR, Vu Lan N. Solar-energy drying systems: A review. Renew Sustain Energy Rev 2009;13:1185210. doi:10.1016/j.rser.2008.08.015.

[10] Palaniappan C. Perspectives of solar food processing in India 2009:1-11.

[11] Sharma AK, Sharma C, Mullick SC, Kandpal TC. Carbon mitigation potential of solar industrial process heating: Paper industry in India. J Clean Prod 2016;112:1683-91. doi:10.1016/j.jclepro.2015.04.093.

[12] Sharma AK, Sharma C, Mullick SC, Kandpal TC. Potential of Solar Energy Utilization for Process Heating in Paper Industry in India: A Preliminary Assessment. vol. 79. Elsevier B.V.; 2015. doi:10.1016/j.egypro.2015.11.486.

[13] Uppal A, Kesari JP. Solar Industrial Process Heat in Indian Automobile Industry 2015;IV:117-23.

[14] Suresh NS, Rao BS. Solar energy for process heating A case study of select Indian industries. J Clean Prod 2017;151:439-51. doi:10.1016/j.jclepro.2017.02.190.

[15] http://ship-plants.info/

[16] Kranzl L, Kalt G, Müller A, Hummel M, Egger C, Öhlinger C, et al. Renewable energy in the heating sector in Austria with particular reference to the region of Upper Austria. Energy Policy 2013;59:17-31. doi:10.1016/j.enpol.2012.08.067.

[17] Schnitzer H, Brunner C, Gwehenberger G. Minimizing greenhouse gas emissions through the application of solar thermal energy in industrial processes. J Clean Prod 2007;15:1271-86. doi:10.1016/j.jclepro.2006.07.023.

[18] Lauterbach C, Schmitt B, Jordan U, Vajen K. The potential of solar heat for industrial processes in Germany. Renew Sustain Energy Rev 2012;16:5121-30. doi:10.1016/j.rser.2012.04.032.

[19] Lauterbach C, Schmitt B, Jordan U, Vajen K. Potential for Solar Process Heat in Germany - Suitable Industrial Sectors and Processes n.d.

[20] Frey P, Fischer S, Drück H, Jakob K. Monitoring Results of a Solar Process Heat System Installed at a Textile Company in Southern Germany. Energy Procedia 2015;70:615-20. doi:10.1016/j.egypro.2015.02.168.

[21] Kurup P, Turchi C. Potential for Solar Industrial Process Heat in the United States. SolarPACES 2015 2015;110001. doi:10.1063/1.4949198.

[22] Schweiger H, Mendes JF, Benz N, Hennecke K, Prieto G, Cusí M, et al. The potential of solar heat in industrial processes. A state of the art review for Spain and Portugal. Eurosun 2000.

[23] Silva R, Cabrera FJ, Pérez-García M. Process heat generation with parabolic trough collectors for a vegetables preservation industry in Southern Spain. Energy Procedia 2014;48:1210-6. doi:10.1016/j.egypro.2014.02.137.

[24] Sturm B, Meyers S, Zhang Y, Law R, Siqueiros Valencia EJ, Bao H, et al. Process intensification and integration of solar heat generation in the Chinese condiment sector - A case study of a medium sized Beijing based factory. Energy Convers Manag 2015;106:1295-308. doi:10.1016/j.enconman.2015.10.045.

[25] Liu Z, Geng Y, Lindner S, Zhao H, Fujita T, Guan D. Embodied energy use in China's industrial sectors. Energy Policy 2012;49:751-8. doi:10.1016/j.enpol.2012.07.016.

[26] Brent AC, Pretorius M. Industrial and commercial opportunities to utilise concentrating solar thermal systems in South Africa. J Energy South Africa 2011;22:15-30.

[27] Uhlig R, Amsbeck L, Buck R, Gobereit B, Schwarzbözl P. Potential High-Temperature Industrial Process Heat Applications for Concentrating Solar Technology in South Africa 2015:537-42.

[28] Joubert EC, Hess S, Van Niekerk JL. Large-scale solar water heating in South Africa: Status, barriers and recommendations. Renew Energy 2016;97:809-22. doi:10.1016/j.renene.2016.06.029.

[29] Ramos C, Ramirez R, Beltran J. Potential assessment in Mexico for solar process heat applications in food and textile industries. Energy Procedia 2013;49:1879-84. doi:10.1016/j.egypro.2014.03.199.

[30] Karagiorgas M, Botzios A, Tsoutsos T. Industrial solar thermal applications in Greece: Economic evaluation, quality requirements and case studies. Renew Sustain Energy Rev 2001;5:157-73. doi:10.1016/S1364-0321(00)00012-5.

[31] Calder W. Australian Energy Update 2014:24. doi:2203-8337.

[32] IT Power. Realising the potential of Concentrating Solar Power in Australia. 2012. 
[33] Osborne J, Analysis E. Australia : Good Funding for Solar Process Heat , but Little Trust by Industry 2016.

[34] Tim Flannery, Sahajwalla V. Critical debate: Australias future. Solar energy 2013:1-47.

[35] U.S. Energy Information Administration. International Energy Outlook 2016. vol. 0484(2016). 2016. doi:www.eia.gov/forecasts/ieo/pdf/0484(2016).

[36] Bahadori A, Nwaoha C. A review on solar energy utilisation in Australia. Renew Sustain Energy Rev 2013;18:1-5. doi:10.1016/j.rser.2012.10.003.

[37] Eglinton T, Hinkley J, Beath A, Dell'Amico M. Potential applications of concentrated solar thermal technologies in the Australian minerals processing and extractive metallurgical industry. Jom 2013;65:1710-20. doi:10.1007/s11837013-0707-z.

[38] Baig MH, Surovtseva D, Halawa E. The Potential of Concentrated Solar Power for Remote Mine Sites in the Northern Territory , Australia 2015;2015.

[39] Fuller RJ. Solar industrial process heating in Australia - Past and current status. Renew Energy 2011;36:216-21. doi:10.1016/j.renene.2010.06.023.

[40] Fuller RJ. Solar Drying in Australia - an Historical Review. Proc Int Sol Energy Soc Conf 2001:859-64.

[41] Beath AC. Industrial energy usage in Australia and the potential for implementation of solar thermal heat and power. Energy 2012;43:261-72. doi:10.1016/j.energy.2012.04.031.

[42] Farjana SH, Huda N, Mahmud MAP, Saidur R. Solar process heat in industrial systems - A global review. Renew Sustain Energy Rev 2018;82:2270-86. doi:10.1016/j.rser.2017.08.065.

[43] European Solar Thermal Industry Federation. Solar Industrial Process Heat. State of the Art. Key Issues Renew Heat Eur 2006:1-15.

[44] Absi Halabi M, Al-Qattan a., Al-Otaibi a. Application of solar energy in the oil industry-Current status and future prospects. Renew Sustain Energy Rev 2015;43:296-314. doi:10.1016/j.rser.2014.11.030.

[45] Author G, Haagen M, Development B, Gmbh IS. Solar Process Heat for Industrial Processes 2013:1-7.

[46] Duffie J a., Beckman W a., Worek WM. Solar Engineering of Thermal Processes, 4nd ed. vol. 116. 2003. doi:10.1115/1.2930068.

[47] Brunner C, Slawitsch B, Giannakopoulou K, Schnitzer H. Industrial Process Indicators and Heat Integration in Industries. Joanneum Res Graz, Österreich 2008.

[48] Goswami DY. Principles of Solar Engineering, Third Edition. vol. 1. 2015. doi:10.1017/CBO9781107415324.004.

[49] Hassine I Ben, Helmke A, Heß S, Krummenacher P, Muster B, Schmitt B, et al. Solar process heat for production and advanced applications 2015:1-5.

[50] Ibrahim OM, Ghoneim AA, Halabi OA, Kamil A. Solar industrial process heat potential in Khartoum, Sudan. Sol Wind Technol 1990;7:649-54. doi:10.1016/0741-983X(90)90039-5.

[51] Kalogirou S. The potential of solar industrial process heat applications. Appl Energy 2003;76:337-61. doi:10.1016/S0306-2619(02)00176-9.

[52] Martin Haagen; Christian Zahler; Elke Zimmermann; Mahmoud M. R. Al-Najami. Solar process steam for pharmaceutical industry in Jordan.pdf. Energy Procedia 2015;70:621-5. doi:10.1016/j.egypro.2015.02.169.

[53] Lauterbach C, Schmitt B, Vajen K, Jordan U. Solar Process Heat in Breweries - Potential and Barriers of a New Application Area. Renew Energy 2009:645-7.

[54] Mauthner F, Hubmann M, Brunner C, Fink C. Manufacture of malt and beer with low temperature solar process heat. Energy Procedia 2014;48:1188-93. doi:10.1016/j.egypro.2014.02.134.

[55] Ogueke N V., Anyanwu EE, Ekechukwu O V. A review of solar water heating systems. J Renew Sustain Energy 2009;1:43106. doi:10.1063/1.3167285.

[56] Shukla A, Singh R, Shukla P. Energy Sustainability Through Green Energy. Green Energy Technol 2015;201:147-62. doi:10.1007/978-81-322-2337-5.

[57] Mekhilef S, Saidur R, Safari A. A review on solar energy use in industries. Renew Sustain Energy Rev 2011;15:1777-90. doi:10.1016/j.rser.2010.12.018

[58] Taibi E, Gielen D, Bazilian M. The potential for renewable energy in industrial applications. Renew Sustain Energy Rev 2012;16:735-44. doi:10.1016/j.rser.2011.08.039.

[59] Tim Flannery, Sahajwalla V. Critical debate: Australias future. Solar energy 2013:1-47.

[60] Vannoni C, Battisti R, Drigo S. Potential for solar heat in indutrial processes. IEA SHC Task 33 and and SolarPACES Task IV: Solar heat for industrial processes. lea 2008:1-21.

[61] Muneer T, Asif M, Cizmecioglu Z, Ozturk HK. Prospects for solar water heating within Turkish textile industry. Renew Sustain Energy Rev 2008;12:807-23. doi:10.1016/j.rser.2006.10.024.

[62] Muneer T, Maubleu S, Asif M. Prospects of solar water heating for textile industry in Pakistan. Renew Sustain Energy Rev 2006;10:1-23. doi:10.1016/j.rser.2004.07.003.

[63] Murray JP. Aluminum Production Using High-Temperature Solar Process Heat. Sol Energy 1999;66:133-42. doi:10.1016/S0038-092X(99)00011-0.

[64] Norton B. Industrial and agricultural applications of solar heat. Compr Renew Energy 2012;3:567-94. doi:10.1016/B978-0-08-087872-0.00317-6

[65] Norton B. Harnessing Solar Heat. Lect Notes Energy 2014;18:9-38. doi:10.1007/978-94-007-7275-5.

[66] Rabab Z, Hafiz A, Nasir A, Muhammad A, Zia ul H. Fabrication and performance study of a solar milk pasteurizer. Pakistan J Agric Sci 2009;46:162-8.

[67] Stewart M, Petrie J. A process systems approach to life cycle inventories for minerals: South African and Australian case studies. J Clean Prod 2006;14:1042-56. doi:10.1016/j.jclepro.2004.08.008.

[68] Suresh NS, Rao BS. Solar energy for process heating A case study of select Indian industries. J Clean Prod 2017;151:439-51. doi:10.1016/j.jclepro.2017.02.190.

[69] Vijayavenkataraman S, Iniyan S, Goic R. A review of solar drying technologies. Renew Sustain Energy Rev 2012;16:2652-70. doi:10.1016/j.rser.2012.01.007.

[70] Wayua FO, Okoth MW, Wangoh J. Design and performance assessment of a flat-plate solar milk pasteurizer for arid pastoral areas of kenya. J Food Process Preserv 2013;37:120-5. doi:10.1111/j.1745-4549.2011.00628.x.

[71] Zahler C, Iglauer O. Solar process heat for sustainable automobile manufacturing. Energy Procedia 2012;30:775-82. doi:10.1016/j.egypro.2012.11.088. 
Highlights:

- In this paper, a systematic review of 10 countries that demonstrated extensive use of solar industrial process heating systems in manufacturing sectors is conducted considering most recent progress.

- This country-wise analysis is then used to identify potential use of solar process heating in Australia.

- The analysis is carried out based on their potential for integration to develop solar heat in industrial processes. Some potential industries are being identified that have the highest potential like Motor vehicles, Textiles, Printing, Wood, Paper, Fabricated metal, Rubber and plastics, chemicals, Food, beverages, electrical equipment, machinery and equipment.

- An overview is given in this paper of available studies focused on specific countries and the industrial heat demand of existing operational plants. Future trends due to solar energy potential are also outlined. 